\title{
Selection in M2 Generation of Black Soybean Using RAPD Markers Associated with Salt Tolerance
}

\author{
Florentina Kusmiyati ${ }^{1}$ Sutarno $^{2}$ and Bagus Herwibawa ${ }^{1 *}$ \\ ${ }^{1}$ Laboratory of Physiology and Crop Breeding \\ ${ }^{2}$ Laboratory of Ecology and Crop Production
}

Faculty of Animal and Agricultural Sciences, Diponegoro University

Tembalang Campus, Semarang 50275, Central Java, Indonesia

*Corresponding author's email: bagus.herwibawa@live.undip.ac.id

\begin{abstract}
The black soybean was mutagenized with gamma rays to increase the genetic variation in our previous article. In this paper, the RAPD markers of black soybean in M2 generation were further analyzed. A total of 9 M2 genotypes were investigated for molecular variations. Furthermore, our PCR results demonstrated that the all markers, associated with salt tolerance, produced different-sized fragments. RAPD analysis detected a total of 32 amplification products, among which 23 were found to be polymorphic. Primer OPAA-01 produced the maximum number of bands (10), while the least number of bands (1) was recorded for primer OPAA-03. The amplified DNA fragments ranged from 303 to 1,931 bp. The maximum polymorphism (100\%) was recorded for the primers OPAA-02 and OPAA-14, while the minimum polymorphism (0\%) was produced by the primer OPAA-03. Analysis of genetic relationship showed there were two groups in the coefficient of 0.55. The first group inluded Detam 3 Prida as salt-sensitive black soybean cultivar and it is closely related with BSMG-160, BSMG-304, BSMG-256, BSMG-352, BSMG-400, BSMG-448, BSMG-496, and BSMG-592 genotypes, sequentially. The second group has only BSMG-208 genotype as an effective out-group. In conclusion, contruction of genetic relationships can be done using RAPD markers and the use of molecular markers will allow a quick selection. Together, our results indicated that, M2 generation showed molecular variations and the strong potential usage for further advances in black soybean breeding.
\end{abstract}

Key Words: Gamma-irradiation, Glycine max, Mutant, Mutation, Stress.

\section{INTRODUCTION}

Black soybean is an important dicot crop due has many advantages, both in terms of health as well as economic [1]. It containing higher protein and lower fat is needed as the material of soy sauce industry, and result in healthier soy sauce with better color and taste due to the high content of glutamate and anthocyanin [2]. Soybean is generally considered as a salt-sensitive glycophytes, which salinity stress inhibits its germination and growth [3], reduces nodules formation, and decreases accumulation of biomass and seed yield [4]. High salinity is one of the most widespread abiotic constraints and constitutes the most serious factor limiting plant distribution and productivity [5]. Salt stress also has various effects on plant ecophysiological processes, such as changes in protective enzyme activities, properties of photosynthesis, mineral distribution, and membrane permeability [6]. Salinity is responsible for ionic and osmotic stresses, firstly ionic stress resulting from salt enters the plant reaching toxic levels, and secondly leads to decreased ability in water uptake, which is reffered to as the water-deficit effect or osmotic stress [7]. Therefore, the demand to develop black soybean cultivar having tolerance to salt-stress is unavoidable.

The black soybean-producing regions in Indonesia are throughout East Java province, and separate breeding programs developed the black soybeans were cultivated in these areas [8]. Detailed characterization of breeding germplasm is a crucial prerequisite for cultivars improvement [9]. DNA markers provide a powerful tool for the cultivar development programs; they are the most widely used in crop breeding and its genetic evaluation, especially for marker assisted evaluation, marker assisted backcrossing, and marker assisted piramiding [10]. Many molecular genetic markers have been used in detecting population genetic structure since 1966, and random amplified polymorphic DNA (RAPD) is the easiest method [11]. RAPD can amplify a large number of loci simultaneously, thereby producing a more representative genome sample than allozymes, so it has become an 
increasingly important tool in genetic analysis [12]. Previously, evaluation of genetic diversity using RAPD markers have been used in Soybean $[13 ; 14]$. Apart from using them in diversity analysis, RAPD markers have been shown to be associated with salt tolerance $[11 ; 15]$.

Mutations induced by gamma-irradiation shows abundant variations, but only the dominant mutation characters are visualized in the M1 generation [16]. In addition, the most identified is lethality at various stages of growth, and its significance is a source for M2 generation, whereas the recessive characters are identified in the M2 generation [17]. Therefore, M2 generation is the most efficient time to screen the mutants, although mutant phenotypes may not be inherited in the next generation due to DNA selfrepair mechanism, consequently, we should analyze mutants in the M3 or M4 generations [18]. Compared with other species, the mutant libraries research on black soybean is relatively limited. In our previous study, a black soybean cultivar Detam 3 Prida was treated by gamma-irradiation, and the molecular variations in M1 generation were analyzed [19]. We further investigate the M2 generation in this gamma-irradiation mutagenized line, and analyzed the RAPD variation in this study. In recent years, DNA polymorphism assays have been used for marker assisted selection. Our works may have considerable significance in salt-tolerant black soybean breeding research.

\section{MATERIALS AND METHODS}

\subsection{Plant Materials and Growth Conditions}

In our previous study, we used 160, 208, 256, 304, 352, 400, 448, 496, 544, and 592 Gy gamma rays-mutagenized black soybean seeds (200 seeds/doses), and 42 genotypes of M2 generation seeds were harvested. Nine of 42 genotypes were analyzed in this study, and $180 \mathrm{M} 2$ individual plants were transplanted in the field located in the Agrotechnopark - Faculty of Animal and Agricultural Sciences - Diponegoro University (-7 3'15.27’'S; $110^{\circ} 26^{\prime} 31.7^{\prime}$ 'E). Seedlings were allowed to grow in the field followed method of Kawasaki et al. [20]. The M2 generation molecular traits were investigated and recorded.

\subsection{DNA Isolation and PCR}

Black soybean DNA was extracted from $1 \mathrm{~g}$ leaf tissue, harvested from healthy leaves of the 30 days after planting, using a modified manufacturer's protocol of the Plant Genomic DNA Kit DP305 (Tiangen Biotech-Beijing Co., Ltd.; China). Extracted DNA samples were tested for quantity and quality with a UV-Vis spectrophotometer NanoDrop ${ }^{\mathrm{TM}} 2000$ (Thermo Fisher Scientific, Inc.; U.S.). Tested DNA samples were then stored at $-21^{\circ} \mathrm{C}$ and kept until used by PCR for RAPD amplification. Six decamer primers viz. OPAA-01: 5'-AGACGGCTCC-3', OPAA-02: 5'-GAGACCAGAC-3', OPAA-03: 5'-TTAGCGCCCC-3', OPAA-09: 5'-AGATGGGCAG-3', OPAA-14: 5'-AACGGGCCAA-3', OPAA-15: 5'-ACGGAAGCCC-3' (Sigma-Aldrich Co., Japan) were dissolved into nuclease free water Invitrogen ${ }^{\text {TM }}$ (Thermo Fisher Scientific, Inc.; U.S.). They were used for RAPD amplification as described by Khan et al. [11]. PCR reactions were carried out in a $25 \mu 1$ of reaction volume containing $22 \mu 1$ AmpliTaq Gold ${ }^{\text {тм }} 360$ Master Mix $(8.5 \mu 1$ nuclease free water, $1 \mu 1360$ GC-Enhancer, $12.5 \mu 1$ AmpliTaq Gold® 360 DNA Polymerase) (Thermo Fisher Scientific, Inc.; U.S.), $1 \mu \mathrm{l}$ primer (15 $\mu \mathrm{M}$ working solution), and $2 \mu \mathrm{l}$ of DNA template (approximately $50 \mathrm{ng} / \mu \mathrm{l}$ ). For DNA amplification, a controlled thermocycler TC9610 MultiGene ${ }^{\mathrm{TM}}$ OptiMax Thermal Cycler (Labnet International, Inc.; U.S.) was initially programmed.

In the first cycle of PCR, activation of PCR Master Mix was carried out at $94{ }^{\circ} \mathrm{C}$ for 10 min and denaturation of DNA template at $94{ }^{\circ} \mathrm{C}$ for $30 \mathrm{sec}$, followed by primer annealing at $38{ }^{\circ} \mathrm{C}$ for $1 \mathrm{~min}$ and primer extension at $72{ }^{\circ} \mathrm{C}$ for 2 min. The next 44 cycles, the period of denaturation, annealing and extension time remained as in the first cycle. Lastly, PCR cycle was the primer final extension at $72{ }^{\circ} \mathrm{C}$ for $8 \mathrm{~min}$ and hold at $4{ }^{\circ} \mathrm{C}$. The amplified products were separated by electrophoresis multiSUB Mini, Mini Horizontal Electrophoresis System (Cleaver Scientific, Ltd.; U.K.) on $1.5 \%$ agarose gel in 1 x TAE buffer. The gel was run at $100 \mathrm{~V}$ constant voltage for $30 \mathrm{~min}$, and then stained with an ethidium bromide solution for 15 min. GeneRuler $100 \mathrm{bp}$ DNALadder Thermo Scientific ${ }^{\text {TM }}$ (Thermo Fisher Scientific, Inc.; U.S.) was used to determine the sizes of the amplified fragments. Next, gel documentation system Uvidoc HD6 (UVItec Ltd., U.K.) were used for the visualization and photography. Band patterns were analyzed by Gel Analyzer software and they were then scored in the binary code. Jaccard's similarity coefficient was used to cluster the genotypes by unweighted pair-group method for arithmetic average analysis (UPGMA) as a simple agglomerative hierarchical clustering method. Finally, dendrogram was drawn using sequential, agglomerative, hierarchical and non-overlaping (SAHN) clustering method as available in NTSYSPc 2.1 Software.

\section{RESULTS AND DISCUSSION}

Six RAPD markers associated with salt tolerance [11, 15,19] were tested on black soybean in M2 generation (Figure 1 and 2). A total of 32 amplification products were generated by these primers, among which 23 were found to be polymorphic (Table 1). Primer OPAA-01 obtained maximum numbers of 10 amplification products, whereas primer OPAA-03 generated minimum numbers of 1 amplification product, so the number of amplification products ranged from 1 to 10 from 6 primers. Interestingly, the molecular weight of the generated bands in the present study ranged from 303 to $1,931 \mathrm{bp}$. Six RAPD products were recorded 
International Journal of Advances in Scientific Research and Engineering (ijasre),Vol 5 (6), June-2019

as unique or genotype specific. These resulted in 335\% polymorphism with an average of 55.83\%. However, different result were reported by earlier researchers in soybean. Polymorphic amplification products were showed in the present study, which were relatively lower than previous reports.

Table 1. Fragment size range, types and number of the amplified DNA bands as well as the polymorphism percentage revealed by six RAPD primers of Detam 3 Prida and black soybean in M2 generation

\begin{tabular}{|l|c|c|c|c|c|c|}
\hline \multirow{2}{*}{ Primer } & \multirow{2}{*}{ Fragment size (bp) } & \multirow{2}{*}{ Monomorphic band } & \multicolumn{2}{|c|}{ Polymorphic bands } & \multirow{2}{*}{ Total bands } & \multirow{2}{*}{ Polymorphism $(\%)$} \\
\cline { 4 - 6 } & & & Unique & Shared & & \\
\hline OPAA-01 & $303-1,931$ & 1 & 4 & 5 & 10 & 90 \\
\hline OPAA-02 & $319-1,273$ & 0 & 1 & 5 & 6 & 100 \\
\hline OPAA-03 & $821-821$ & 1 & 0 & 0 & 1 & 0 \\
\hline OPAA-09 & $346-862$ & 4 & 0 & 1 & 5 & 20 \\
\hline OPAA-14 & $346-1,167$ & 0 & 1 & 5 & 6 & 100 \\
\hline OPAA-15 & $363-754$ & 3 & 0 & 1 & 4 & 25 \\
\hline Total & & 9 & 6 & 17 & 32 & 335 \\
\hline Mean & & 1.50 & 1.00 & 2.83 & 5.33 & 55.83 \\
\hline
\end{tabular}
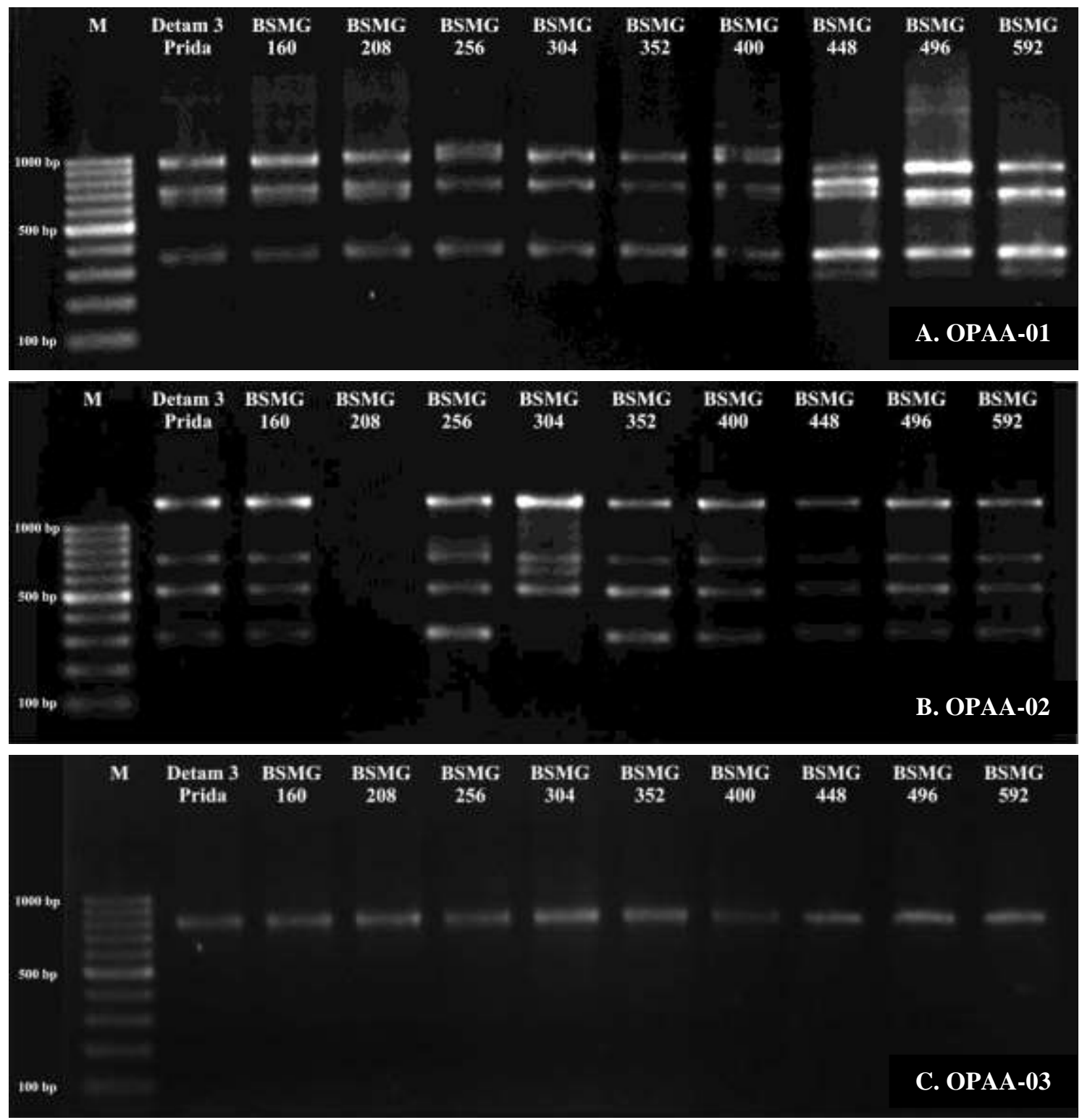

Figure 1. Amplification profiles of Detam 3 Prida and M2 generation of black soybean DNA samples using RAPD primers (A = OPAA-01, B = OPAA-02, and C = OPAA-03). M= 1000 bp DNA ladder 
International Journal of Advances in Scientific Research and Engineering (ijasre),Vol 5 (6), June-2019


Figure 2. Amplification profiles of Detam 3 Prida and M2 generation of black soybean DNA samples using RAPD primers (A = OPAA-09, B = OPAA-14, and C = OPAA-15). M= 1000 bp DNA ladder

Khan et al. [11], Mahgoub et al. [15], Tidke and Jadhav [21], Choudhury et al. [22], and Tidke et al. [13] reported 98.17 \%, $87.74 \%, 84.67 \%, 83.57 \%$, and $73.69 \%$ polymorphism among soybean genotypes in their RAPD study, respectively. Hamzekhanlu et al. [23] observed a lower level (67.50\%) of DNA polymorphism among $33 \mathrm{M} 7$ generation soybean mutant lines after analysis with RAPD markers. Different reports on the levels of observed polymorphism in their soybean studies could be attributed to the precise nature of the genetic materials that was from different geographical regions, thus having relatively large genetic variation, and also many different sequences of the primers were used under investigation. However, our results are in agreement with our previous study which also reported very low polymorphism (38.00\%) of black soybean in M1 generation [19].

The RAPD based genetic relation clearly formed a very divergent group (Figure 3) and genetic relation of Detam 3 Prida and black soybean in M2 generation are presented in the (Table 2). According to Saeed et al. [24], the genetic relation with coefficient that was more than 0.60 showed the close relation among the genotypes. In our study, relationship among the genotypes were separated into two groups in the coefficient of 0.55 , namely group I and II. Group I on the coefficient of 0.70 was separated into group A and B. The analysis of group A was started by considering Detam 3 Prida as salt-sensitive black soybean cultivar [25]; it is closely related with M2 generation derived from 160 - $400 \mathrm{~Gy}$ of gamma rays. Meanwhile, group B consisted of M2 generation derived from $448-592 \mathrm{~Gy}$ of gamma rays. It has been explained that increasing of mutagen doses increased the genetic distances coefficient, and predicted the previous mutagen treatments are not contribute much to salt tolerance. On the contrary, group II has only BSMG-208 genotype as an effective out-group. 


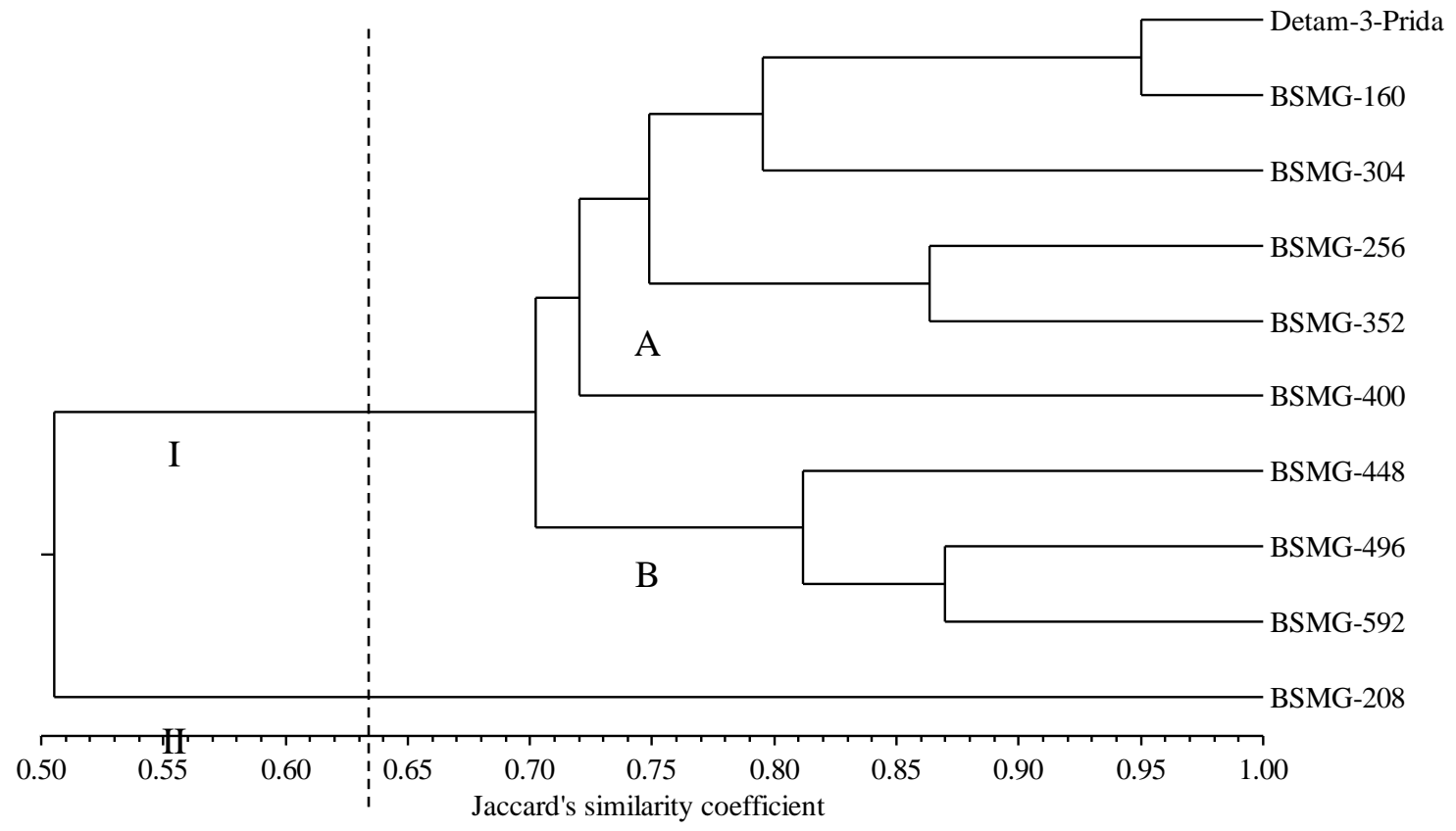

Figure 3. Dendrogram of Detam 3 Prida and black soybean in M2 generation based on RAPD

RAPD markers have been efficiently used for evaluation of genetic relationship between soybean cultivars [26, 27, 28] and among different lines of soybean mutants [23, 29]. In addition, they have also been used for evaluation under salt stress in rice [30], wheat [31], barley [32], cotton [33], maize [34], soybean [35], and petunia [36]. Salt tolerance differences among the genotypes could be related to the difference in the genetic distances coefficient. So, the less different in salt tolerance are indicated by the more genetically similar genotypes. Our data supports that genetic instability induced by gamma-rays in M2 generation was reflected by changes in RAPD profile: disappearance of bands and appearance of new bands occurred in the profiles in comparison to control. Nevertheles, it is evident that RAPD markers can efficiently distinguish all of the genotypes which associated with salinity tolerance.

Table 2. Genetic similarity matrix of Detam 3 Prida and black soybean in M2 generation generated by RAPD

\begin{tabular}{|c|c|c|c|c|c|c|c|c|c|c|}
\hline & $\begin{array}{c}\text { Detam-3- } \\
\text { Prida } \\
\end{array}$ & $\begin{array}{c}\text { BSMG- } \\
160 \\
\end{array}$ & $\begin{array}{c}\text { BSMG- } \\
208 \\
\end{array}$ & $\begin{array}{c}\text { BSMG- } \\
256 \\
\end{array}$ & $\begin{array}{c}\text { BSMG- } \\
304 \\
\end{array}$ & $\begin{array}{c}\text { BSMG- } \\
352 \\
\end{array}$ & $\begin{array}{c}\text { BSMG- } \\
400\end{array}$ & $\begin{array}{c}\text { BSMG- } \\
448 \\
\end{array}$ & $\begin{array}{c}\text { BSMG- } \\
496 \\
\end{array}$ & $\begin{array}{c}\text { BSMG- } \\
592 \\
\end{array}$ \\
\hline Detam-3-Prida & 1.000 & & & & & & & & & \\
\hline BSMG-160 & 0.950 & 1.000 & & & & & & & & \\
\hline BSMG-208 & 0.550 & 0.600 & 1.000 & & & & & & & \\
\hline BSMG-256 & 0.667 & 0.708 & 0.435 & 1.000 & & & & & & \\
\hline BSMG-304 & 0.773 & 0.818 & 0.524 & 0.708 & 1.000 & & & & & \\
\hline BSMG-352 & 0.773 & 0.818 & 0.524 & 0.864 & 0.818 & 1.000 & & & & \\
\hline BSMG-400 & 0.720 & 0.760 & 0.500 & 0.731 & 0.630 & 0.760 & 1.000 & & & \\
\hline BSMG-448 & 0.739 & 0.708 & 0.435 & 0.750 & 0.640 & 0.783 & 0.667 & 1.000 & & \\
\hline BSMG-496 & 0.680 & 0.720 & 0.458 & 0.630 & 0.593 & 0.654 & 0.679 & 0.760 & 1.000 & \\
\hline BSMG-592 & 0.773 & 0.818 & 0.524 & 0.708 & 0.667 & 0.739 & 0.692 & 0.864 & 0.870 & 1.000 \\
\hline
\end{tabular}

Determination of RAPD-specific markers were enabled by polymorphism of RAPD bands. However, further experimentation required to be done to determine the linkage between the genes responsible for salt tolerance and RAPD markers in the next 
generation of black soybean. This make it possible that these markers have the potential to be mapped onto the soybean genome for locating the positions of corresponding chromosomal regions, where the salt-sensitive and salt-tolerance genes are situated. Evaluation of salinity tolerance in soybean is often difficult and needs long time, but tolerance to salinity is different in growth stages, thus breeding and screening for salinity tolerance require a rapid and reliable technique. The evaluation of genetic distance together with salt tolerance ability provides some useful information for assisting plant breeders in selecting interested genotypes.

\section{CONCLUSIONS}

Detam 3 Prida was considering as salt-sensitive black soybean cultivar, and it is closely related with BSMG-160, BSMG-304, BSMG-256, BSMG-352, BSMG-400, BSMG-448, BSMG-496, and BSMG-592 genotypes, sequentially. The black soybean in M2 generation derived from previous study might not contribute much to improvement in salt tolerance. In addition, BSMG-208 genotype is an effective out-group. Our data suggest that RAPD is a good molecular markers to assess genetic diversity of black soybean in M2 generation and examine these genetic relationships. Therefore, this study may help breeders in selecting genetically diverse seed source for salt tolerance and strong potential usage for next step of breeding in black soybean.

\section{ACKNOWLEDGMENT}

We want to convey our gratitude to The Directorate General of Research and Community Service, The Ministry of Research, Technology and Higher Education of The Republic of Indonesia for the research grant through scheme of "Excellence Higher Education Institution Research", and Diponegoro University for the continuous support, particularly to the Institute of Research and Community Services.

\section{REFERENCES}

1. Fetriyuna, "The potential of darmo black soybean varieties as an alternative of a promising food for future." International Journal on Advanced Science Engineering Information Technology, vol. 5, no. 1, pp. 44 -46, 2015

2. S. Purwanti, D.R. Immawati, and D. Prajitno, "The study on the seed storability of black soybean (Glycine max L. Merrill) intercropped with sweet sorghum (Sorghum bicolor L. Moench).” Planta Tropika, vol. 6, no.2, pp. 116 - 121, 2018

3. R. Guan, J. Chen, J. Jiang, G. Liu, Y. Liu, L. Tian, L. Yu, R. Chang, and L. Qiu, "Mapping and validation of a dominant salt tolerance gene in the cultivated soybean (Glycine max) variety Tiefeng 8." The Crop Journal, vol. 2, no. 6, pp. 358 365,2014

4. P. H. Putri, G. W. A. Susanto, and R. Artari, "Response of soybean genotypes to salinity in germination stage." Nusantara Bioscience, vol. 9, no. 2, pp. 133-137, 2017

5. B. Gupta, and B. Huang, "Mechanism of salinity tolerance in plants: physiological, biochemical, and molecular characterization.” International Journal of Genomics, 701596, 2014

6. J. K. Sun, T. Li., J. B. Xia, J. Y. Tian, Z. H. Lu, and R. T. Wang, "Influence of salt stress on ecophysiological parameters of Periploca sepium Bunge.” Plant, Soil and Environment, vol. 57, no. 4, pp. 139-144, 2011

7. F. Kusmiyati, Sutarno, M. G. A. Sas, and B. Herwibawa, "Mutagenic effects of gamma rays on soybean (Glycine max L.) germination and seedlings." IOP Conference Series: Earth and Environmental Science, 102: 012059, 2018

8. M. M. Adie, Suharsono, and Sudaryono, "Black soybean prospects of detam-1 and detam-2 varieties." Buletin Palawija, vol. 18, pp. 66 - 72, 2009 (In Indonesian)

9. K. V. Fels, and R. J. Snowdon, "Understanding and utilizing crop genome diversity via high-resolution genotyping." Plant Biotechnology Journal, vol. 14, no. 4, pp. 1086 - 1094, 2015

10. M. Govindaraj, M. Vetriventhan, and M. Srinivasan, "Importance of genetic diversity assessment in crop plants and its recent advances: an overview of its analytical perspectives." Genetics Research Internasional, 431487, 2015

11. F. Khan, K. R. Hakeem, T. O. Siddiqi, and A. Ahmad, "RAPD markers associated with salt tolerance in soybean genotypes under salt stress.” Applied Biochemistry and Biotechnology, vol. 170, no. 2, pp. 257-272, 2013

12. V. Sharma, N. Belwal, B. Kamal, A. K. Dobriyal, and V. S. Jadon, "Assessment of genetic fidelity of in vitro raised plants in Swertia chirayita through ISSR, RAPD analysis and peroxidase profiling during organogenesis." Brazilian Archives of Biology and Technology, 59: e16160389, 2016

13. S. A. Tidke, D. Ramakrishna, S. Kiran, G. Kosturkova, and G. A. Ravishankar, "Analysis of genetic diversity of 12 genotypes of Glycine max using RAPD marker." International Journal of Current Microbiology and Applied Sciences, vol. 6, no.7, pp. $656-663,2017$

14. H. M. Abdelmigid, and M. M. Morsi, "Genetic fidelity testing of soybean plants under allelopathic stress of Eucalyptus ground leaves through RAPD and ISSR markers.” International Journal of Botany, vol. 14, no.1, pp. 14-23, 2018 
15. H. A. M. Mahgoub, A. R. Sofy, E. A. A. Azeem, and M. S. A. Zahra, "Molecular markers associated with salt-tolerance of different soybean (Glycine max L.) cultivars under salt stress." International Journal of Advanced Research in Biological Sciences, vol. 3, no. 8, pp. 241-267, 2016

16. B. Herwibawa, Sakhidin, and T. A. D. Haryanto, "Peroxidase isozyme from rice in $\mathrm{M}_{1}$ generation under drought stress." Bioscience Research, vol. 15, no. 2, pp. 744-753, 2018

17. S. Kumar, G. Katna, and N. Sharma, "Mutation breeding in chickpea." Advances in Plants and Agriculture Research, vol. 9, no. 2, pp. $355-362,2019$

18. X. Xi-ou, L. Wenqiu, L. Wei, G. Xiaoming, L. Lingling, M. Feiyue, and L. Yuge, "The analysis of physiological variations in $\mathrm{M}_{2}$ generation of Solanum melongena L. mutagenized by ethyl methane sulfonate." Frontiers in Plant Science, vol. 8, no. 17, 2017

19. F. Kusmiyati, Sutarno, M. G. A. Sas and B. Herwibawa, "Genetic diversity of induced mutation soybean at saline soil based on RAPD markers.” Prosiding Perhimpunan Ilmu Pemuliaan Indonesia (PERIPI) Komda Sumatera Barat, Padang 4 - 5 October 2018 (In Indonesian).

20. Y. Kawasaki, R. Yamazaki, and K. Katayama, "Effects of late sowing on soybean yields and yield components in southwestern Japan.” Plant Production Science, vol. 21, no. 4, pp. 339-348, 2018

21. S. D. Tidke, and A. J. Jadhav, "Molecular characterization of different varieties of Glycine max L. using RAPD marker." Trends in Biosciences, vol. 11, no. 25, pp. 3342-3346, 2018

22. P. R. Choudhury, S. K. Pandey, R. K. Gupta, V. S. Meena, and A. B. Mandal, "DNA profiling and inter-relationship among soybean cultivars using random primers." Vagetos - An International Journal of Plant Research, vol. 30 , no. special-1, pp. 216-219, 2017

23. M. Y. Hamzekhanlu, A. I. Darbandi, N. P. Beiranvand, M. T. Hallajian, and A. Majdabadi, "Phenotypic and molecular analysis of M7 generation of soybean mutant lines through random amplified polymorphic DNA (RAPD) marker and some morphological traits." African Journal of Agricultural Research, vol. 6, no. 7, pp. 1779-1785, 2011

24. A. Saeed, H. Hovsepyan, R. Darvishzadeh, M. Imtiaz, S. K. Panguluri, and R. Nazaryan, "Genetic diversity of iranian accessions, improved lines of chickpea (Cicer arietinum L.) and their wild relatives by using simple sequence repeats." Plant Molecular Biology Reporter, vol. 29, no. 4, pp. 848-858, 2011

25. M. G. A. Sas, F. Kusmiyati, S. Anwar, and B. Herwibawa, "Agronomic traits and RAPD markers for diversity analysis in soybean [Glycine $\max (\mathrm{L}$.) Merill] mutant using gamma rays at saline soil." International Conference on Genetic Resources and Biotechnology (ICGRB), Bogor, 20-21 August 2018

26. M. G. AL-Saghir, and A. S. G.A. Salam, "Genetic diversity of north american soybean (Glycine max L.) cultivars as revealed by RAPD markers.” Journal of Plant Sciences, vol. 6, no. 1, pp. 36-42, 2011

27. M. K. Imran, S. S. Sultana, and S. S. Alam, "Differential chromosome banding and RAPD analysis in three varieties of Glycine max (L.) Merr.” Cytologia, vol. 80, no. 4, pp. 447-455, 2015

28. R. K. Jain, A. Joshi, and D. Jain, "Molecular marker based genetic diversity analysis in soybean (Glycine max L. Merrill) genotypes." International Journal of Current Microbiology and Applied Sciences, vol. 6, no. 6, pp. 1034-1044, 2017

29. E. L. Arumingtyas, W. Widoretno, and S. Indriyani, "Somaclonal variations of soybeans (Glycine max L. Merr) stimulated by drought stress based on random amplified polymorphic DNAs (RAPDs)." American Journal of Molecular Biology, vol. 2, pp. 85-91, 2012

30. S. M. Mansuri, N. B. Jelodar, and N. Bagheri, "Evaluation of rice genotypes to salt stress in different growth stages via phenotypic and random amplified polymorphic DNA (RAPD) marker assisted selection." African Journal of Biotechnology, vol. 11, no. 39, pp. 9362-9372, 2012

31. Z. S. Omran, H. S. Muhammed, A. S. A. Al-Sahib, and K. M. Ibrahim, "In vitro screening of three Iraqi wheat (Triticum aestivum L.) genotypes for salt tolerance.” The Egyptian Journal of Experimental Biology (Botany), vol. 9, no. 2, pp. 193-197, 2013

32. A. Temel, "Comparison of salinity-induced changes in two cultivars of barley." IUFS Journal of Biology, vol. 73, no. 2, pp. $9-16,2014$

33. B. Saleh, "DNA changes in cotton (Gossypium hirsutum L.) under salt stress as revealed by RAPD marker." Advances in Horticultural Sciences, vol. 30, no. 1, pp. 13-21, 2016

34. T. B. Saputro, S. Dianawati, N. F. Sholihah, and D. Ermavitalini, "Genetic diversity of improved salt tolerant calli of maize (Zea mays L.) using RAPD.” AIP Conference Proceedings, 1854: 020033, 2017

35. Juwarno, and S. Samiyarsih, "Anatomical and molecular responses of soybean (Glycine max L. Merr) due to salinity stresses." Molekul, vol. 12, no.1, pp. 45-52, 2017

36. M. K. Malkiewicz, and A. Bienias, "BSA and molecular markers screening for salt stress tolerant mutant of Petunia obtained in in vitro culture." Ciencia Rural, Santa Maria, vol. 48, no. 12, e20170042, 2018 